\title{
Effects on Soil and Crop Properties of Forms of Sowing, Deferral Intervals and Fertilisation of the Annual Winter Forage in a Crop-Livestock Integration System
}

\author{
Milton da Veiga ${ }^{1,2}$, Carla Maria Pandolfo ${ }^{1,2}$, Alvadi Antonio Balbinot Junior ${ }^{3} \&$ Leandro Durigon $^{4}$ \\ ${ }^{1}$ Epagri Experimental Station of Campos Novos, Campos Novos, SC, Brazil \\ ${ }^{2}$ University of West Santa Catarina, Campos Novos, SC, Brazil \\ ${ }^{3}$ Embrapa National Center for Soybean Research, Londrina, PR, Brazil \\ ${ }^{4}$ Agronomist Engineering (Private), Campos Novos, SC, Brazil \\ Correspondence: Milton da Veiga, University of West Santa Catarina, SC 135, km 180, n 2500, P.O. Box 250, \\ Z.C. 89620-000, Campos Novos, SC, Brazil. E-mail: milton.veiga.br@gmail.com
}

Received: February 1, 2016 Accepted: March 23, 2016 Online Published: April 15, 2016

doi:10.5539/jas.v8n5p15 URL: http://dx.doi.org/10.5539/jas.v8n5p15

\begin{abstract}
The use of cropland to grow annual winter forages that are managed using direct grazing can affect the quality of the soil and the yield of summer crops grown in succession. This study aimed to evaluate the effect that the form of sowing (direct sowing and sowing + harrowing), the deferral intervals (ungrazed and grazing stopped at 14 days and 28 days before and on the day of forage desiccation) and the fertilisation of the annual winter forage (with and without application of $8 \mathrm{~m}^{3} \mathrm{ha}^{-1}$ of poultry litter) had on the chemical properties of soil, resistance to penetration, residual forage biomass, soil cover and yield of corn and soybean from the third to the sixth year of experimentation. The forms of sowing did not affect the chemical properties of the soil, resistance to penetration, the residual forage biomass and the yield of the soybean and corn grown in rotation. The grazing of annual winter forage did not affect the chemical properties of soil and the yield of soybean and corn grown in succession, but residual forage biomass was reduced and resistance to penetration was increased with decreasing deferral intervals. In turn, the fertilisation of winter forages improved the quality of the chemical properties of the soil and increased the residual forage biomass and crop yields in most of the four years examined in this experiment.
\end{abstract}

Keywords: corn, manure, soybean

\section{Introduction}

Crop-livestock integration systems (CLIS) have been used for millennia, but since the 20th century there has been a tendency to use more specialised production systems (Russelle, Entz, \& Franzluebbers, 2007). However, currently there is a renewed interest in reintegrating crops with livestock due to concerns about the degradation of natural resources, the profitability and stability of farm income and increased regulation on cattle feeding using concentrates (Fontaneli, Santos, \& Mori, 2006; Russele et al., 2007; Franzluebbers \& Stuedemann, 2007; Sulc \& Tracy, 2007; Balbinot Junior, Moraes, Veiga, Pelissari, \& Dieckow, 2009).

The integration of crops and forages in soil that is managed under no-tillage could be environmentally beneficial since conservation agriculture is enhanced by the diversity of the system, creating alternative nutrients flows and other common processes in nature (Carvalho et al., 2010). Although the diversity of the system might still be low, these studies have noted that the integration of crops and forages increases the biomimetism of nature and allows for a higher level of system organisation. According to Franzluebbers (2007), opportunities to integrate crops and livestock are abundant in regions with a temperate climate, such as the areas found throughout the southeastern United States (U.S.) and southern Brazil, but it is also possible in regions with a cold climate (Sulc \& Tracy, 2007) or a dry climate (Vilela et al., 2011).

Forage and animal management systems impact crop production in different ways. Lunardi et al. (2008) observed that the soybean yield was higher when forages were grazed in comparison to when they were not grazed. In turn, Moraes, Neumann, and Novakowiski (2011) determined that the yield of corn was not affected 
by grazing and that there was a quadratic effect on grain yield due to the increase in the nitrogen $(\mathrm{N})$ levels in both winter forages and corn. Fertilisation with sources containing $\mathrm{N}$ can be a strategy to increase the production of annual winter forages (Assmann et al., 2004; Chintala, McDonald, \& Bryan, 2012) and the regrowth of the forage after deferring (Assmann, Ronzelli Junior, Moraes, Assmann, Koehler, \& Sandini, 2003), providing greater ground cover during grazing and during the initial development of subsequent crops, and even increasing the concentration of total soil organic carbon (Costa et al., 2012). In Southern Brazil, the availability of poultry manure on many farms can be an important source of nutrients for both the winter forages and the summer crops.

In CLIS, the cycling of nutrients is enhanced in relation to farming systems without animals. This statement was confirmed by Oliveira, Becquer, Goedert, Vilela, and Deleporte (2011), who found that the ion concentrations in soil with continuous grazing and CLIS was always low, at a soil depth of $1.5 \mathrm{~m}$, indicating high cycling and a low risk of mobile nutrients as potassium (K) leaching into the soil. Ferreira, Anghinoni, Andrighetti, Martins, and Carvalho (2011) observed that the cycling of $\mathrm{K}$ increased with increasing grazing intensity, and this cycling was determined by the amount of dry grassland that was eaten by the animals and not by the type of litter used or by the sequential planting of soybean. Additionally, they determined that the balance in the system was negative; the largest deficit occurred in areas with a higher grazing intensity without affecting the soybean yield in soils where the availability of $\mathrm{K}$ remained high. This confirmed the fertilization recommendations for that region (SBCS, 2004). After using six CLIS methods in an oxisol over the course of eight years, Santos, Fontaneli, Spera, and Tomm (2009) observed acidification in the soil at a depth of 0-0.05 m, and increased levels of organic matter, phosphorus $(\mathrm{P})$ and $\mathrm{K}$, in the soil at a depth of $0-0.1 \mathrm{~m}$.

The deferral interval, or the interval between when grazing is stopped and the forage is desiccated, is another relevant factor that must be considered. Ricce, Alves, and Prete (2011) found that the deferral interval did not affect the soybean yield. Veiga, Durigon, Pandolfo, and Balbinot Junior (2012) also observed this for soybean and corn. However, there might be differences in responses between the genotypes in terms of the degree of soil compaction, and especially the residual forage biomass (Debiasi \& Franchini, 2012). Additionally, many farms using CLIS still employ harrowing to incorporate the seeds of the annual winter forage. Harrowing accelerates the decomposition of residues from the previous crop because cuts and incorporates partially it straw into the soil surface layer, making the soil more susceptible to erosion at the beginning of the forage cycle and also reducing the soil's resistance to compaction (Silva, Reinert, \& Reichert, 2000) by animal trampling during direct grazing. As cattle have hooves that are approximately $0.1 \mathrm{~m}$ in diameter, compaction via trampling is not expected below a depth of 0.10-0.15 m, except when the soil is very loose or when it is near the critical level of moisture content when it has low resistance to compaction and the forces applied on the surface might promote compaction at greater depths (Soehne, 1958; Greenwood \& Mckenzie, 2001; Fernández, Alvarez, \& Taboada, 2011).

This present study evaluated the effect that the form of sowing, the deferral intervals and the fertilisation of annual winter forage had on the chemical properties of soil, the resistance to penetration, the residual forage biomass, the soil cover and the yield of corn and soybean grown in succession, over the course of three to six years of experimentation.

\section{Material and Methods}

The experiment was conducted from the third to the sixth year of an experiment conducted in Campos Novos Council, Santa Catarina State, in southern Brazil $\left(27^{\circ} 27^{\prime} \mathrm{S}, 51^{\circ} 24^{\prime} \mathrm{W}\right.$; at an altitude of $\left.987 \mathrm{~m}\right)$ in clayey oxisol with an approximate average slope of $12 \%$. At the beginning of the experiment, the soil depth layer of $0-0.2 \mathrm{~m}$ had: a soil $\mathrm{pH}$ in water of $6.1 ; 24.2 \mathrm{mg} \mathrm{L}^{-1}$ of extractable $\mathrm{P} ; 223 \mathrm{mg} \mathrm{L}^{-1}$ of exchangeable $\mathrm{K} ; 8.9 \mathrm{cmol}_{\mathrm{c}} \mathrm{L}^{-1}$ and 3.3 $\mathrm{cmol}_{\mathrm{c}} \mathrm{L}^{-1}$ of exchangeable calcium $(\mathrm{Ca})$ and magnesium $(\mathrm{Mg})$, respectively; it also consisted of $3.8 \%$ of organic matter and $610 \mathrm{~g} \mathrm{~kg}^{-1}$ of clay, all determined in accordance with the methodology described in Tedesco, Gianello, Bissani, Bohnen, and Volkweiss (1995).

Prior the beginning of the experiment was used a crop rotation with forage (black oat) grazed with cattle using continuous variable stock in the autumn/winter seasons, and soybean or corn for grain production in the spring/summer seasons. The experimental design was a randomised complete block, with four replications in subplots. In the main plots, $10 \mathrm{~m} \times 20 \mathrm{~m}$ areas were allocated two different forms of sowing for the annual winter forage (direct sowing and sowing + harrowing). Direct sowing was performed using a seeder with a double-disc in rows spaced $0.17 \mathrm{~m}$ apart. The sowing + harrowing was performed with a "tandem" device comprised of cutting disks in the front row and flat disks in the second row, revolving a superficial layer of approximately $0.05 \mathrm{~m}$ of soil. In the $5 \mathrm{~m} \times 10 \mathrm{~m}$ sub-split plots, four deferral intervals were used (ungrazed and grazing stopped 14 days and 28 days before and on the day of the desiccation of the residual forage biomass). In the $5 \mathrm{~m} \times 5 \mathrm{~m}$ sub-subplots, forage fertilisation was evaluated, with and without application of $8 \mathrm{~m}^{3} \mathrm{ha}^{-1}$ of 
poultry litter (50\% at 20 days after forage sowing and $50 \%$ at 28 days before desiccation). After six years of forage fertilisation with poultry litter were applied $13.5 \mathrm{t} \mathrm{ha}^{-1}$ of dry matter (DM) with an average $\mathrm{pH}$ of 8.1 , totaling 378, 333, 343, 496, 180, 30 and $7 \mathrm{~kg} \mathrm{ha}^{-1}$ of $\mathrm{N}, \mathrm{P}_{2} \mathrm{O}_{5}, \mathrm{~K}_{2} \mathrm{O}, \mathrm{Ca}, \mathrm{Mg}$, zinc (Zn) and copper $(\mathrm{Cu})$, respectively.

The animals in the ungrazed paddocks were isolated using an electric fence and the animals had free access to other paddocks during the grazing period until the date of deferral, when they were also isolated using an electric fence. Continuous grazing with variable stock was adopted in order to maintain a forage height ranging between $0.1 \mathrm{~m}$ and $0.2 \mathrm{~m}$ high. The residual forage biomass was evaluated on the day of desiccation by collecting $0.25 \mathrm{~m}^{2}$ of shoot biomass from the sub-subplot, which was dried at $60^{\circ} \mathrm{C}$ to a constant mass and calculated as $\mathrm{kg} \mathrm{ha}^{-1}$ of dry matter (DM).

The sowing of summer crops was conducted using a planter equipped with a furrow element resembling a "chisel", with an action depth of approximately $0.1 \mathrm{~m}$, in rows spaced $0.8 \mathrm{~m}$ apart for the corn and $0.45 \mathrm{~m}$ apart for the soybean, using 60,000 seeds $\mathrm{ha}^{-1}$ and 300,000 seeds $^{-1} \mathrm{a}^{-1}$ for the corn and soybean, respectively. At the time of sowing, $350 \mathrm{~kg} \mathrm{ha}{ }^{-1}$ of formulated fertiliser 10-20-20 (N- $\left.\mathrm{P}_{2} \mathrm{O}_{5}-\mathrm{K}_{2} \mathrm{O}\right)$ was applied to the corn and 0-20-20 was applied to the soybean. The seeds of both cultures were treated with fungicide and insecticide, and the soybean seeds were inoculated with Bradirhizobium. For the corn, $200 \mathrm{~kg} \mathrm{ha}^{-1}$ of ammonium nitrate was applied in coverage. The application of post-emergent herbicide and pesticide treatments followed the technical recommendations for each crop used in the region. The yield was determined in a floor area of $9.6 \mathrm{~m}^{2}$ per plot for corn and $5.4 \mathrm{~m}^{2}$ per plot for soybean; those values were corrected to account for $13 \%$ moisture, and the results are expressed in $\mathrm{kg} \mathrm{ha}^{-1}$.

At the end of the sixth year of experimentation, soil samples were collected to determine the chemical properties by collecting four subsamples from each sub-subplot, in soil depth layers of 0-0.05 m, 0.05-0.10 m, 0.10-0.20 m and 0.20-0.40 m. The samples were analysed using the routine methods described Tedesco et al. (1995). The percentage of bare soil was determined based on digital photos taken immediately after sowing the annual winter forage and the summer crops, using the methodology described in Veiga, Reinert, and Reichert (2010). In the last year of the experiment, profiles of penetration resistance at the time of desiccation of the winter forage and after harvesting the summer crop were determined in three points per sub-subplot when the sampled profile showed uniform moisture close to field capacity (two days after rain that dampened the entire profile), using a SoloTrack Falker penetrometer, at a constant rate of penetration and a record of penetration resistance measured in $0.01 \mathrm{~m}$ increments.

The data were tested for normality and homogeneity of variance and analysed using Analysis Of Variance (ANOVA) and the F-test, applying a comparison of the treatment means when significant differences were observed (Tukey, $\mathrm{p}<0.05$ ). To determine the chemical properties of the soil and the soil penetration resistance, statistical analysis was performed individually for each of the sampled layers.

\section{Results and Discussion}

The form of sowing and the deferral intervals of the winter forage had no effect on the chemical properties of the soil that were evaluated in this study; moreover, no interaction was found between the factors that were investigated. The amount of nutrients applied during the six years of forage fertilisation with poultry litter resulted in a significant increase in the $\mathrm{pH}$ in water and the concentration of most of the nutrients studied in the soil layer with a depth of $0-0.05 \mathrm{~m}$, reaching a depth of up to $0.20 \mathrm{~m}$ in the case of $\mathrm{K}, \mathrm{P}$ and $\mathrm{Zn}$ (Figure 1), thereby improving the potential for nutrient cycling in the crop-livestock system (Carvalho et al., 2010). Only the content of the exchangeable $\mathrm{Ca}$ did not increase significantly in any of the sampled layers, probably because the increase provided by the poultry litter was low compared to the level found in the soil at the beginning of the experiment, showing $8.9 \mathrm{cmol}_{\mathrm{c}} \mathrm{L}^{-1}$ in the soil layer with a depth of $0-0.20 \mathrm{~m}$. 
$\mathrm{pH}$ in water

Extractable $\mathrm{P}, \mathrm{mg} \mathrm{L}^{-1}$

Exchangeable K, mg L ${ }^{-1}$
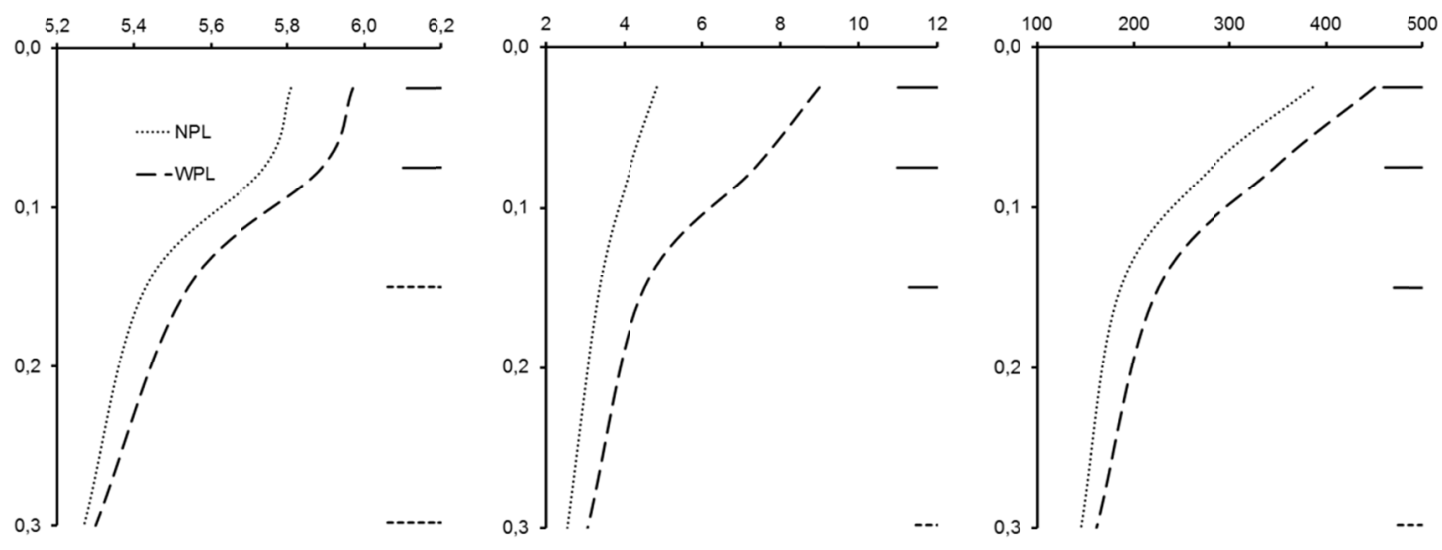

Exchangeable $\mathrm{Ca}, \mathrm{cmol}_{\mathrm{c}} \mathrm{L}^{-1}$

Exchangeable $\mathrm{Mg}, \mathrm{cmol}_{\mathrm{c}} \mathrm{L}^{-1}$

Base saturation, $\%$
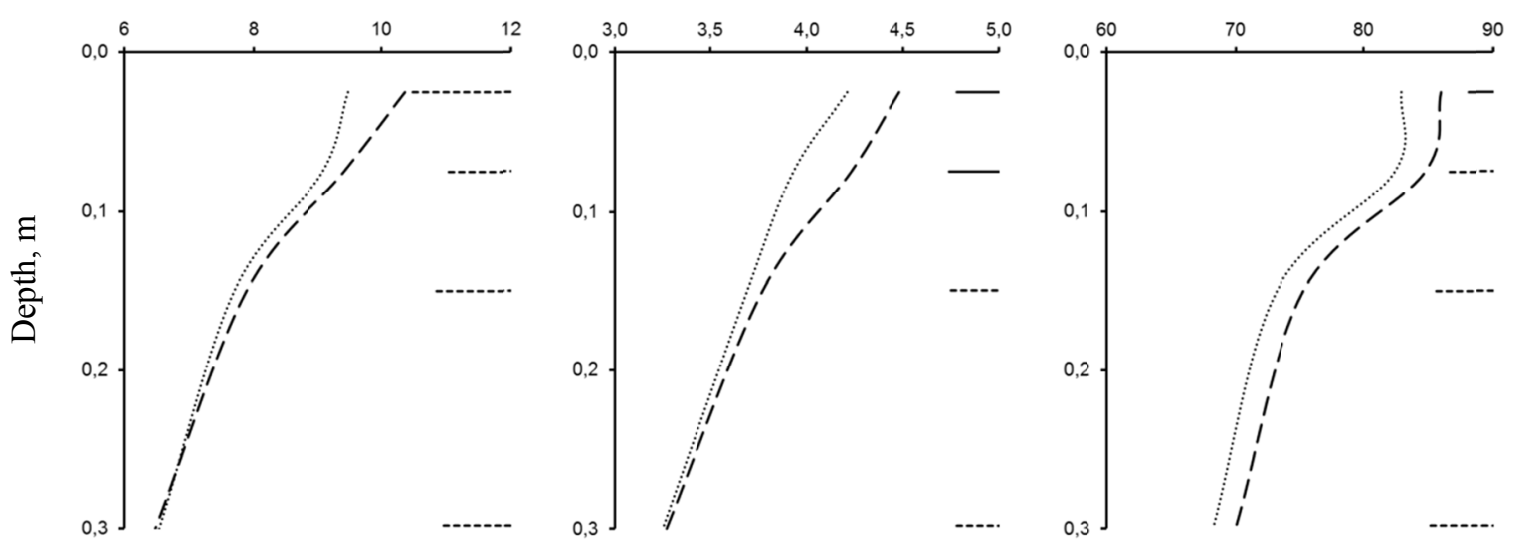

Organic matter, $\mathrm{g} \mathrm{kg}^{-1}$

Extractable $\mathrm{Zn}, \mathrm{mg} \mathrm{L}^{-1}$

Extractable $\mathrm{Cu}, \mathrm{mg} \mathrm{L}^{-1}$
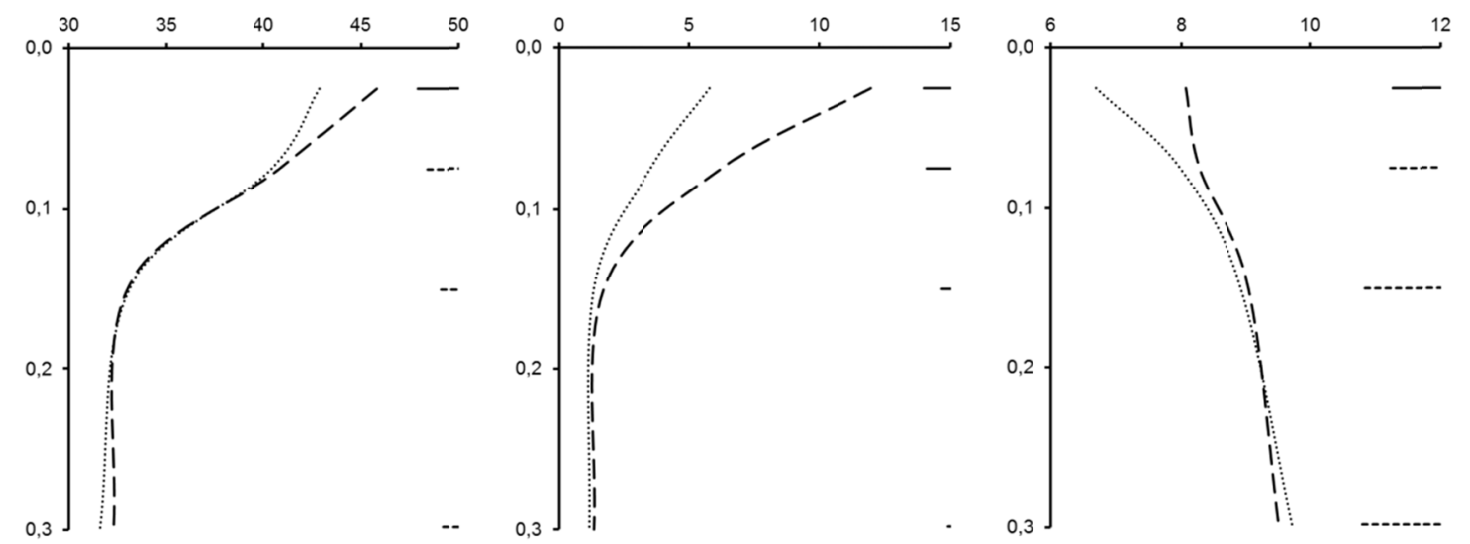

Figure 1. Profiles of the Soil Chemical Properties of Oxisol. Properties determined after six years of applying or not applying poultry litter to annual winter forage in a crop-livestock system (average of two forms of sowing and four deferral intervals)

Note. NPL: no poultry litter; WPL: with poultry litter.

The increase in the soil $\mathrm{pH}$ as a function of the organic fertiliser is related to the application of quicklime in the poultry litter during the period in which it is used in the aviary. It is possible that a fraction of the unreacted quicklime promoted the release of hydroxyl, thus increasing the soil $\mathrm{pH}$, as also observed by Veiga, Reinert, and 
Pandolfo (2006) in a long-term experiment conducted on the same soil class. Ernani (2003) analysed the chemical composition of various poultry litter samples from the Rio Grande do Sul State and found a neutralisation value of approximately $10 \%$ in these materials. In turn, the increase in the organic matter content in the surface layer is due to the presence of shavings in the poultry litter, an organic material with a high C:N ratio that is resistant to biodegradation, resulting in a greater proportion of humus being added to the soil (Camargo, Santos, \& Guerra, 1999; Chintala et al., 2014). Furthermore, the increased levels of most nutrients allowed for greater biomass production of roots and shoots in the winter forage and the summer crops, contributing to the accumulation of organic matter in the topsoil (Costa et al., 2012). These results demonstrate the potential use of poultry litter, a resource that is available at several farms in the Midwestern and Western regions of Santa Catarina State, as fertilizer for a crop-livestock system.

We observed an increase in resistance to penetration by reducing the deferral interval down to a soil depth of approximately $0.05 \mathrm{~m}$ at the time of forage desiccation (Figure 2A), which indicated that animal trampling could cause superficial soil compaction, as also pointed out by Greenwood and Mckenzie (2001) and Fernández et al. (2011). We observed that, after finishing the forage grazing period, this resistance was gradually reduced by natural processes, mainly due to the decomposition of the forage roots and the cycles of soil wetting and drying (Horn \& Rostek, 2000). These natural processes are complete until the end of the subsequent summer crop cycle when no difference in resistance to penetration in this layer was observed. At that time, higher resistance to penetration was observed in the soil layer depths ranging from $0.10 \mathrm{~m}$ to $0.15 \mathrm{~m}$ in treatments with trampling (Figure 2B). Since this increased resistance at a deeper layer was not observed at the time of desiccation it might not be related to the pressure exerted by the cattle hooves, which can result in a significant depth value up to an equivalent width of the applied pressure (Horn \& Rostek, 2000), which corresponds to a cattle hoof diameter of approximately $0.1 \mathrm{~m}$. However, the values for resistance to penetration were not high enough to restrict root grow at both time of determination or in any of the soil layers that were sampled, which is greater than $2.0 \mathrm{MPa}$ in a soil moisture value that is near field capacity, according to Reichert, Suzuki, and Reinert (2007).

Penetration resistance, $\mathrm{MPa}$

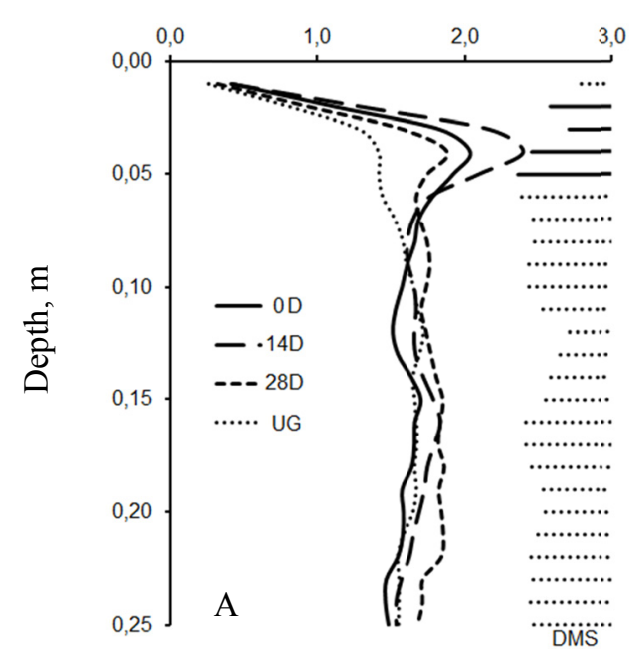

After finishing forage grazing period

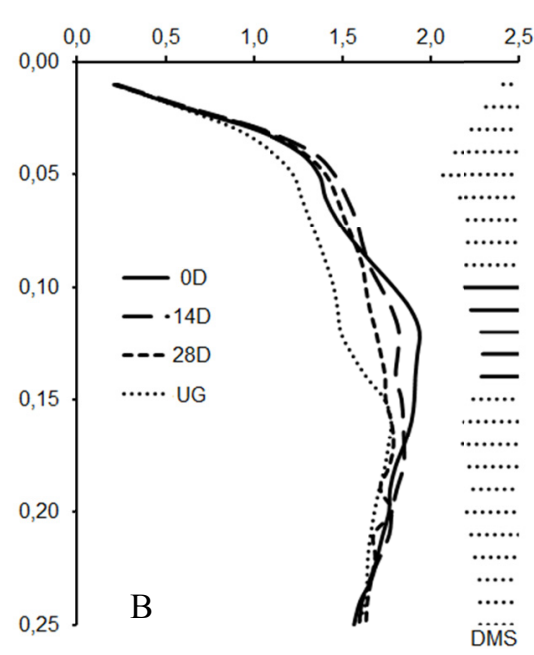

After harvesting subsequente cropp

Figure 2. Profile of Soil Penetration Resistance in Four Deferral Intervals. Findings determined at the desiccation time (A) and after harvesting the following summer crop (B)

Note. UG: ungrazed; 0D, 14D and 28D, deferred interval before desiccation of, respectively, 0,14 and 28 days.

The residual DM of the winter forage was not influenced by the form of sowing used in the forage and the interactions among the experimental factors. However, it was influenced by the deferral intervals in all of the years evaluated and by fertilisation with poultry litter in most of years (Table 1). The amount of residual DM varied between the studied years, depending on the crop species and the climatic conditions. With respect to the deferral interval, in all four years no differences were found in the reduction of residual DM by removing the 
grazing animals on the day of desiccation (0D) or 14 days (14D) or 28 days (28D) prior to desiccation than was observed when the forage was not grazed. Similar results were observed by Nicoloso, Lanzanova, and Lovato (2006) and Ricce et al. (2012), who found a reduction in the production of mulch to cover the soil with increasing intensity of cattle grazing in the winter.

Table 1. Residual dry matter of the winter forage as a function of the form of sowing, the deferral intervals and the winter forage fertilisation from the third to the sixth year of experimentation

\begin{tabular}{|c|c|c|c|c|}
\hline \multirow{2}{*}{ Factor/Treatment } & \multicolumn{4}{|c|}{ Year - Forage } \\
\hline & Year 3 - BO & Year 4 - BO & Year $5-\mathrm{BO}+\mathrm{HV}$ & Year 6 - BO \\
\hline & ---------------- & ----------------- & 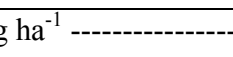 & ---------------- \\
\hline \multicolumn{5}{|c|}{ Forms of sowing the forage } \\
\hline DS & $5765^{\mathrm{ns}}$ & $2113^{\mathrm{ns}}$ & $2987^{\mathrm{ns}}$ & $3983^{\mathrm{ns}}$ \\
\hline $\mathrm{SH}$ & 4604 & 2094 & 3096 & 3702 \\
\hline \multicolumn{5}{|c|}{ Deferral intervals of the forage } \\
\hline $0 \mathrm{D}$ & $1854 \mathrm{~b}$ & 2902 c & $4558 \mathrm{~b}$ & $1415 \mathrm{~b}$ \\
\hline $14 \mathrm{D}$ & $2309 \mathrm{~b}$ & $3147 \mathrm{bc}$ & $4553 \mathrm{~b}$ & $1180 \mathrm{~b}$ \\
\hline $28 \mathrm{D}$ & $2375 \mathrm{~b}$ & $3555 \mathrm{~b}$ & $4673 \mathrm{~b}$ & $1691 \mathrm{~b}$ \\
\hline SP & $5628 \mathrm{a}$ & $5768 \mathrm{a}$ & $6483 \mathrm{a}$ & $2922 \mathrm{a}$ \\
\hline \multicolumn{5}{|c|}{ Fertilization of the forage } \\
\hline No & $2823 \mathrm{~b}$ & $3688 \mathrm{~b}$ & $5002^{\mathrm{ns}}$ & $1621 \mathrm{~b}$ \\
\hline With & $3260 \mathrm{a}$ & 3998 a & 5082 & $1983 \mathrm{a}$ \\
\hline
\end{tabular}

Note. BO: black oat; HV: hairy vetch; DS: direct sowing; SH: sowing + harrowing; UG: ungrazed; 0D, 14D and 28D, deferred interval before desiccation of, respectively, 0, 14 and 28 days.

Within each factor, means followed by the same letters in columns do not differ significantly (Tukey, p $<0.05$ ); ns: no significant difference.

The form used to sow the winter forage affected the percentage of bare soil (Table 2), while the deferral intervals changed the percentage of bare soil after sowing the summer crops (Table 3 ) in three from four years that were studied. The percentage of bare soil was higher when sowing + harrowing was used for seeding the winter forage, simulating a common practice among farmers who realise the benefits of broadcast seeding and the incorporation of seeds through harrowing. This effect depends on the preceding crop, being higher after soybean than after corn; it also depends on the agricultural year in terms of the amount of straw remaining after harvest. The percentage of bare soil after sowing the summer crops is mainly related to the amount of residual forage biomass, and it does not vary much between years; it has a higher value when the forage is ungrazed and it decreases with the reduction in the deferral interval. Thus, incorporating the forage seeds through harrowing as well as reducing the deferral intervals results in soil cover conditions that increase the risk of erosion in the period between sowing and the full development of the subsequent crop, once the risk of erosion increases due to a reduction in the percentage of the soil covered by the DM residues (Lopes, Cogo, \& Levien, 1987). 
Table 2. Percentage of bare soil after sowing the winter forage as a function of the form of sowing, the deferral intervals and the fertilisation of the winter forage, from the third to the sixth year of experimentation

\begin{tabular}{|c|c|c|c|c|}
\hline \multirow{2}{*}{ Factor/Treatment } & \multicolumn{4}{|c|}{ Year - Previous crop } \\
\hline & Year 3 - Corn & Year 4 - Soybean & Year 5 - Soybean & Year 6-Corn \\
\hline
\end{tabular}

Forms of sowing the forage

\begin{tabular}{|c|c|c|c|c|}
\hline DS & $1 \mathrm{~b}$ & $50 \mathrm{~b}$ & $49^{\mathrm{ns}}$ & $3^{\mathrm{ns}}$ \\
\hline $\mathrm{SH}$ & $4 \mathrm{a}$ & $83 \mathrm{a}$ & 53 & 8 \\
\hline \multicolumn{5}{|c|}{ Deferral intervals of the forage } \\
\hline $0 \mathrm{D}$ & $3^{\text {ns }}$ & $69 \mathrm{a}$ & $56^{\mathrm{ns}}$ & $7^{\mathrm{ns}}$ \\
\hline $14 \mathrm{D}$ & 2 & $67 \mathrm{a}$ & 55 & 5 \\
\hline $28 \mathrm{D}$ & 3 & $69 \mathrm{a}$ & 48 & 6 \\
\hline SP & 2 & $60 \mathrm{~b}$ & 45 & 5 \\
\hline
\end{tabular}

Fertilization of the forage

$\begin{array}{lllcc}\text { No } & 2^{\text {ns }} & 66^{\text {ns }} & 51^{\text {ns }} & 7^{\text {ns }} \\ \text { With } & 2 & 67 & 51 & 5\end{array}$

Note. DS: direct sowing; SH: sowing + harrowing; UG: ungrazed; 0D, 14D and 28D, deferred interval before desiccation of, respectively, 0,14 and 28 days.

Within each factor, means followed by the same letters in columns do not differ significantly (Tukey, p $<0.05$ );

ns: no significant difference.

Table 3. Percentage of bare soil after sowing the summer crops as a function of the form of sowing, the deferral intervals and the fertilisation of the winter forage, from the third to the sixth year of experimentation

\begin{tabular}{|c|c|c|c|c|}
\hline \multirow{2}{*}{ Factor/Treatment } & \multicolumn{4}{|c|}{ Year - Previous forage } \\
\hline & Year 3 - BO & Year 4 - BO & Year $5-\mathrm{BO}+\mathrm{HV}$ & Year $6-\mathrm{BO}$ \\
\hline & ---------------. & ----------- & \% ----------------- & --------------- \\
\hline \multicolumn{5}{|c|}{ Forms of sowing the forage } \\
\hline DS & $28^{\mathrm{ns}}$ & $30^{\mathrm{ns}}$ & $27^{\mathrm{ns}}$ & $30^{\mathrm{ns}}$ \\
\hline $\mathrm{SH}$ & 33 & 33 & 28 & 33 \\
\hline \multicolumn{5}{|c|}{ Deferral intervals of the forage } \\
\hline oD & $32^{\mathrm{ns}}$ & $39 a$ & $39 a$ & $43 \mathrm{a}$ \\
\hline 14D & 31 & $33 \mathrm{a}$ & $31 \mathrm{a}$ & $40 \mathrm{a}$ \\
\hline $28 \mathrm{D}$ & 31 & $35 \mathrm{a}$ & $26 \mathrm{ab}$ & $28 \mathrm{~b}$ \\
\hline SP & 29 & $19 \mathrm{~b}$ & $16 \mathrm{~b}$ & $15 \mathrm{c}$ \\
\hline \multicolumn{5}{|c|}{ Fertilization of the forage } \\
\hline No & $30^{\mathrm{ns}}$ & $34^{\mathrm{ns}}$ & $30^{\text {ns }}$ & $33^{\mathrm{ns}}$ \\
\hline With & 31 & 29 & 26 & 30 \\
\hline
\end{tabular}

Note. BO: black oat; HV: hairy vetch; DS: direct sowing; SH: sowing + harrowing; UG: ungrazed; 0D, 14D and 28D, deferred interval before desiccation of, respectively, 0,14 and 28 days.

Within each factor, means followed by the same letters in columns do not differ significantly (Tukey, p $<0.05$ ); ns: no significant difference.

The corn and soybean yield was not affected by the form of sowing and the deferral intervals of the winter forage from the third to the sixth year of experimentation (Table 4). These results indicate that the yield of these crops in succession to forage is not affected when moderate grazing pressure is used, which is in agreement with the results obtained by Lunardi et al. (2008), Balbinot Junior et al. (2011) and Moraes et al. (2011). Additionally, the 
present study's results demonstrate that the time between when the grazing is stopped and the sowing of summer crops occurs does not have much relevance when the forage is maintained at an appropriately high level during the grazing period, as discussed by Balbinot Junior et al. (2009). In the present study, the yield of corn was high compared to the regional average, reaching $13,350 \mathrm{~kg} \mathrm{ha}^{-1}$ on average across all plots, which is the result of favorable climatic conditions, the use of genotypes with high potential, the application of proper fertiliser and other cultural management practices. In turn, the average yield of soybean varied between $3,321 \mathrm{~kg}^{-1}$ and $5,486 \mathrm{~kg} \mathrm{ha}^{-1}$, which was also related to the climatic conditions favorable to that crop, especially in the sixth year of experimentation. These data demonstrate the possibility of obtaining a high yield of soybean and corn grown after the annual winter forage in a CLIS, combining the production of cattle meat or milk in the autumn/winter seasons and grain in the spring/summer seasons.

Table 4. Grain yield of summer crops as a function of the form of sowing, the deferral intervals and the fertilisation of the winter forage, from the third to the sixth year of experimentation

\begin{tabular}{|c|c|c|c|c|}
\hline \multirow{2}{*}{ Factor/Treatment } & \multicolumn{4}{|c|}{ Year - Crop } \\
\hline & Year 3 - Soybean & Year 4 - Soybean & Year 5 - Corn & Year 6 - Soybean \\
\hline & --------------------- & ----------------- kg & $\mathrm{l}^{-1}$------------ & ---------------------- \\
\hline \multicolumn{5}{|c|}{ Forms of sowing the forage } \\
\hline DS & $3882^{\text {ns }}$ & $3345^{\mathrm{ns}}$ & $13199^{\mathrm{ns}}$ & $5453^{\mathrm{ns}}$ \\
\hline $\mathrm{SH}$ & 4002 & 3296 & 13500 & 5519 \\
\hline \multicolumn{5}{|c|}{ Deferral intervals of the forage } \\
\hline $0 \mathrm{D}$ & $4021^{\mathrm{ns}}$ & $3380^{\text {ns }}$ & $13417^{\mathrm{ns}}$ & $5388^{\mathrm{ns}}$ \\
\hline $14 \mathrm{D}$ & 3889 & 3310 & 13600 & 5426 \\
\hline $28 \mathrm{D}$ & 3919 & 3287 & 13120 & 5562 \\
\hline SP & 3940 & 3305 & 13261 & 5569 \\
\hline \multicolumn{5}{|c|}{ Fertilization of the forage } \\
\hline No & $3550 \mathrm{~b}$ & $3263^{\text {ns }}$ & $12817 \mathrm{~b}$ & $5419 \mathrm{~b}$ \\
\hline With & $4334 \mathrm{a}$ & 3379 & $13882 \mathrm{a}$ & $5553 \mathrm{a}$ \\
\hline
\end{tabular}

Note. BO: black oat; HV: hairy vetch; DS: direct sowing; SH: sowing + harrowing. UG: ungrazed; 0D, 14D and 28D, deferred interval before desiccation of, respectively, 0,14 and 28 days.

Within each factor, means followed by the same letters in columns do not differ significantly (Tukey, p $<0.05$ ); ns. no significant difference.

The fertilisation of the winter forage with poultry litter increased the yield of corn grown in succession (Table 4). This was mainly because the application of manure promoted an increase in the levels of various nutrients and in the amount of organic matter in the soil over time (Figure 1), favoring the growth and development of the corn grown in succession. Assmann et al. (2003) and Moraes et al. (2011) also found an increased yield of corn when nitrogen fertilisation of the winter forage preceded the sowing of summer crops. This demonstrates that corn is very responsive to increased nutrient availability, especially N. Similarly when poultry litter was used, the soybean yield was higher in two of the three years that were investigated with this crop in this study, because the soil fertility as a whole improved after this crop and it had little or no response to $\mathrm{N}$ because of the symbiotic fixation of this nutrient. In this context, poultry litter can be used to increase the yield of the annual winter forage and the summer crops sown in succession.

\section{Conclusions}

For the winter forage, the form of sowing (direct sowing or sowing + harrowing) does not alter the chemical properties of the soil, the resistance to penetration, the residual biomass of the forage and the yield of soybean and corn grown in succession; however, harrowing increases the percentage of bare soil after sowing the winter forage.

The grazing of the annual winter forage does not alter the chemical properties of the soil and the yield of soybean and corn grown in succession in relation to the absence of grazing; however, it reduces the residual 
forage biomass and the soil cover when the summer crops are sown. Increasing the deferral interval does not change the chemical properties of the soil or the yield of soybean and corn from the third to the sixth year of experiment.

The fertilisation of the winter forage with poultry litter improves the chemical properties of the soil quality after six years of experimentation. It also increases the residual forage biomass and the grain yield of those crops in three from four years investigated in this study.

\section{References}

Assmann, A. L., Pelissari, A., Moraes, A., Assmann, T. S., Oliveira, E. B., \& Sandini, I. (2004). Produção de gado de corte e acúmulo de matéria seca em sistemas de integração lavoura-pecuária em presença e ausência de trevo branco e nitrogênio. Revista Brasileira de Zootecnia, Viçosa, 33, 37-44.

Assmann, T. S., Ronzelli Junior, P., Moraes, A., Assmann, A. L., Koehler, H. S., \& Sandini, I. (2003). Rendimento de milho em área de integração lavoura-pecuária sob sistema plantio direto, em presença e ausência de trevo branco, pastejo e nitrogênio. Revista Brasileira de Ciência do Solo, Viçosa 27, 675-683. http://dx.doi.org/10.1590/S0100-06832003000400012

Balbinot Junior, A. A., Moraes, A., Veiga, M., Pelissari, A., \& Dieckow, J. (2009). Integração lavoura-pecuária-intensificação de uso de áreas agrícolas. Ciência Rural, 39, 2340-2346. http://dx.doi.org/10.1590/S0103-84782009005000107

Balbinot Junior, A. A., Veiga, M., Moraes, A., Pelissari, A., Mafra, A. L., \& Dela Piccolla, C. (2011). Winter pasture and cover crops and their effects on soil and summer grain crops. Pesquisa Agropecuária Brasileira, 4, 1357-1363. http://dx.doi.org/10.1590/S0100-204X2011001000032

Camargo, F. A. O., Santos, G. A., \& Guerra, J. G. M. (1999). Macromoléculas e substâncias húmicas. In G. A. Santos \& F. A. O. Camargo (Eds.), Fundamentos da matéria orgânica do solo (pp. 27-39). Evangraf: Porto Alegre.

Carvalho, P. C. F., Anghinoni, I., Moraes, A., Souza, E. D., Sulc, R. M., Lang, C. R., ... Bayer, C. (2010). Managing grazing animals to achieve nutrient cycling and soil improvement in no-till integrated systems. Nutrient Cycling in Agroecosystems, 88, 259-273. http://dx.doi.org/10.1007/s10705-010-9360-x

Chintala, R., McDonald, L. M., \& Bryan, W. B. (2012). Optimization of water potential and nutrient levels for Kentucky bluegrass-white clover mixture on acidic soils. Biotechnology, Agronomy, Society and Environment, 16, 167-177.

Chintala, R., Schumacher, T. E., Kumar, S., Malo, D. D., Rice, J., Bleakley, B., ... Gu, Z. R. (2014). Molecular characterization of biochar materials and their influence on microbiological properties of soil. Journal of Hazardous Materials, 279, 244-256. http://dx.doi.org/10.1016/j.jhazmat.2014.06.074

Costa, N. R., Andreotti, M., Gioia, M. T., Tarsitano, M. A. A., Pariz, C. M., \&, Buzetti, S. (2012). Análises técnicas e econômicas no sistema de integração lavoura-pecuária submetido à adubação nitrogenada. Revista Ceres, 59, 597-605. http://dx.doi.org/10.1590/S0034-737X2012000500004

Debiasi, H., \& Franchini, J. C. (2012). Atributos físicos do solo e produtividade da soja em sistema de integração lavoura-pecuária com braquiária e soja. Ciência Rural, 42, 1180-1186. http://dx.doi.org/10.1590/S0103-84782012000700007

Ernani, P. R. (2003). Disponibilidade de nitrogênio e adubação nitrogenada para a macieira (pp. 76). UDESC: Lages.

Fernández, P. L., Alvarez, C. R., \& Taboada, M. A. (2011). Assessment of topsoil properties in integrated crop-livestock and continuous cropping systems under zero tillage. Soil Research, 49, 143-151. http://dx.doi.org/10.1071/SR10086

Ferreira, E. V. O., Anghinoni, I., Andrighetti, M. H., Martins, A. P., \& Carvalho, P. C. F. (2011). Ciclagem e balanço de potássio e produtividade de soja na integração lavoura-pecuária sob semeadura direta. Revista Brasileira de Ciência do Solo, 35, 161-169. http://dx.doi.org/10.1590/S0100-06832011000100015

Fontaneli, R. S., Santos, H. P., \& Mori, C. (2006). Lucratividade e risco de sistemas de produção de grãos com pastagens, sob sistema plantio direto. Ciência Rural, 36, 51-57. http://dx.doi.org/10.1590/S0103-84782006000100008

Franzluebbers, A. J. (2007). Integrated crop-livestock systems in the southeastern USA. Agronomy Journal, 99, 361-372. http://dx.doi.org/10.2134/agronj2006.0076 
Franzluebbers, A. J., \& Stuedemann, J. A. (2007). Crop and cattle responses to tillage systems for integrated crop-livestock production in the Southern Piedmont, USA. Renewable Agriculture and Food Systems, 22, 168-180. http://dx.doi.org/10.1017/S1742170507001706

Greenwood, K. L., \& Mckenzie, B. M. (2001). Grazing effects on soil physical properties and the consequences for pastures: A review. Animal Production Science, 41, 1231-1250. http://dx.doi.org/10.1071/EA00102

Horn, R., \& Rostek, J. (2000). Subsoil compaction processes-State of knowledge. In R. Horn, J. J. H. Akker, \& J. Arvidsson (Eds.), Subsoil compaction: Distribution, processes and consequences. Advances in Geoecology (Vol. 32, pp. 44-54).

Lopes, P. R. C., Cogo, N. P., \& Levien, R. (1987). Eficácia relativa de tipo e quantidade de resíduos culturais espalhados uniformemente sobre o solo na redução da erosão hídrica. Revista Brasileira de Ciência do Solo, $11,71-75$.

Lunardi, R., Carvalho, P. D. F., Trein, C. R., Costa, J. A., Cauduro, G. F., Barbosa, C. M. P., \& Aguinaga, A. A. Q. (2008). Rendimento de soja em sistema de integração lavoura-pecuária: Efeito de métodos e intensidades de pastejo. Ciência Rural, 38, 795-801. http://dx.doi.org/10.1590/S0103-84782008000300032

Moraes, I. E. S. A., Neumann, A. P. M., \& Novakowiski, M. K. F. J. H. (2011). Efeito residual do nitrogênio na cultura do milho no sistema de produção integração lavoura-pecuária. Ciência Rural, 41, 1315-1322. http://dx.doi.org/10.1590/S0103-84782011005000099

Nicoloso, R. S., Lanzanova, M. E., \& Lovato, T. (2006). Manejo das pastagens de inverno e potencial produtivo de sistemas de integração lavoura-pecuária no Estado do Rio Grande do Sul. Ciência Rural, 36, 1799-1805. http://dx.doi.org/10.1590/S0103-84782006000600020

Oliveira, M. I. L., Becquer, T., Goedert, W. J., Vilela, L., \& Deleporte, P. (2011). Concentração de íons na solução de um Latossolo Vermelho sob diferentes sistemas de manejo. Pesquisa Agropecuária Brasileira, 46, 1291-1300. http://dx.doi.org/10.1590/S0100-204X2011001000025

Reichert, J. M., Suzuki, L. E. A. S., \& Reinert, D. J. (2007). Compactação do solo em sistemas agropecuários e florestais: identificação, efeitos, limites críticos e mitigação. Tópicos em Ciência do Solo, 5, 49-134.

Ricce, W. S., Alves, S. J., \& Prete, C. E. C. (2012). Época de dessecação de pastagem de inverno e produtividade de grãos de soja. Pesquisa Agropecuária Brasileira, 46, 1220-1225. http://dx.doi.org/10.1590/S0100-204X2011001000015

Russelle, M. P., Entz, M. H., \& Franzluebbers, A. J. (2007). Reconsidering integrated crop-livestock systems in North America. Agronomy Journal, 99, 325-334. http://dx.doi.org/10.2134/agronj2006.0139

Santos, H. P., Fontaneli, R. S., Spera, S. T., \& Tomm, G. O. (2009). Efeito de sistemas de produção integração lavoura-pecuária (ILP) pecuária (ILP) sobre a fertilidade do solo em plantio direto sobre a fertilidade do solo em plantio direto. Acta Scientiarum Agronomy, 31, 719-727. http://dx.doi.org/10.4025/actasciagron.v31i4.925

Silva, V. R., Reinert, D. J., \& Reichert, J. M. (2000). Densidade do solo, atributos químicos e sistema radicular do milho afetados pelo pastejo e manejo do solo. Revista Brasileira de Ciência do Solo, 24, 191-199. http://dx.doi.org/10.1590/S0100-06832000000100021

Sociedade Brasileira de Ciência do Solo. (2004). Manual de adubação e de calagem para os estados do Rio Grande do Sul e de Santa Catarina (10th ed., p. 394). SBCS/Núcleo Regional Sul/Comissão de Química e Fertilidade do Solo RS/SC. Porto Alegre: Evangraf.

Soehne, W. (1958). Fundamentals of pressure distribution and soil compaction under tractor tires. Agricultural Engineering, 39, 276-281.

Sulc, R. M., \& Tracy, B. F. (2007). Integrated crop-livestock systems in the US Corn Belt. Agronomy Journal, 99, 335-345. http://dx.doi.org/10.2134/agronj2006.0086

Tedesco, M. J., Gianello, C., Bissani, C. A., Bohnen, H., \& Volkweiss, S. J. (1995). Análises de solo, plantas e outros materiais (2nd ed., p. 174). UFRGS: Porto Alegre. Boletim técnico, 5.

Veiga, M., Durigon, L., Pandolfo, C. M., \& Balbinot Junior, A. A. (2012). Atributos de solo e de plantas afetados pelo manejo da pastagem anual de inverno em sistema de integração lavoura-pecuária. Ciência Rural, 42, 444-450. http://dx.doi.org/10.1590/S0103-84782012000300010

Veiga, M., Reinert, D. J., \& Pandolfo, C. M. (2006). Efeito de sistemas de preparo e de fontes de nutrientes sobre 
a fertilidade do solo e o crescimento e produção de milho. Agropecuária Catarinense, 19, 69-73.

Veiga, M., Reinert, D. J., \& Reichert, J. M. (2010). Tillage systems and nutrient sources affecting soil cover, temperature and moisture in a clayey Oxisol under corn. Revista Brasileira de Ciência do Solo, 34, 2011-2020. http://dx.doi.org/ 0.1590/S0100-06832010000600025

Vilela, L., Martha Junior, G. B., Macedo, M. C. M., Marchão, R. L., Guimarães Júnior, R., Pulrolnik, K., \& Maciel, G. A. (2011). Sistemas de integração lavoura-pecuária na região do Cerrado. Pesquisa Agropecuária Brasileira, 46, 1127-1138. http://dx.doi.org/10.1590/S0100-204X2011001000003

\section{Copyrights}

Copyright for this article is retained by the author(s), with first publication rights granted to the journal.

This is an open-access article distributed under the terms and conditions of the Creative Commons Attribution license (http://creativecommons.org/licenses/by/3.0/). 